WE investigated morphological alterations induced by s.c. in jection of $2.5 \mu \mathrm{g}$ of Bothrops jararaca venom in rats. In tense disorganisation of collagen fibres $w$ as observed $1 \mathrm{~m}$ in after the venom injection, particularly at regions near vessels and nerves. Mast cells were degranulated, and erythrocytes were seen leaving venules throughout the endothelial junctions. At th is time, damaged endothelial cells were not observed. In rats envenomed as above, but immediately after cardiorespiratory failure induced by deep ether anaesthesia, alterations in the connective tissue structures, as previously described, were not observed. The mediation of this haemorrhage was investigated by injecting the venom in to the foot pad of mice and compared to the mediation of oedema. Local haemorrhage was significantly reduced in mice pre-treated with capsaicin or guanethidine or submitted to a surgical section of sciatic and saphenous nerves. In these animals, oedema was not affected. Groups treated with methysergide or morphine showed both haemorrhage and oedema significantly reduced. Indomethacin or dexamethasone pre-treatments significantly reduced the oedema, but not the haemorrhage. Moreover, in animals treated with promethazine or mepyramine, oedema and haemorrhage were not affected. These data suggest that local haemorrhage induced by Bothrops jararaca venom is partially controlled by serotonin and neurohumoral mediators. Furthermore, results indicate that haemorrhage and oedema are mediated by different pharmacological systems.

Key words: Snake venom, Bothrops jararaca, Local haemorrhage, Oedema, Neurogenic inflammation

\section{Local haemorrhage induced by Bothrops jararaca venom: relationship to neurogenic inflammation}

\author{
Luis Roberto C. Gonçalves ${ }^{1, C A}$ and Mario Mariano²
}

${ }^{1}$ Laboratorio de Fisiopatologia, Instituto Butantan, Av. Vital Brazil, 1500, 05503-900; and ${ }^{2}$ Disciplina de Imunologia, Universidade Federal de São Paulo, Escola Paulista de Medicina, São Paulo-SP, Brazil

\author{
${ }^{\mathrm{CA}}$ Corresponding Author \\ Tel: $5511813-7222$ ext. 2164 \\ Fax: $5511813-7222$ ext. 2162 \\ Email:1rcg@uol.com.br
}

\section{Introduction}

Haemorrhage and oedema, besides blood coagulation disturbances, are the main signs of envenoming by Bothrops snake venoms. ${ }^{1,2}$ Despite serum therapy being an effective treatment for the control of systemic symptoms in this type of envenoming, it does not control the oedema and local haemorrhagic and necrotic lesions which develop at the site of venom inoculation. ${ }^{1,3-5}$

Among the toxins responsible for these local effects, haemorrhagic factors were isolated from various viperid venoms. ${ }^{6}$ Even though some of these haemorrhagic factors are devoid of proteolytic activities, ${ }^{7-11}$ they are characterised as metalloproteinases. ${ }^{6}$ Some of these factors digest proteins from the extracellular matrix, and this property has been related to the pathogeny of haemorrhagic lesions. ${ }^{6,12-17}$

On the other hand, efforts have also been made to characterise the pharmacological mediators involved in oedema formation, ${ }^{18-23}$ pain $^{24}$ and other para- meters of the inflammatory response $e^{25-29}$ induced by viperid venoms. Nevertheless, all this information is not sufficient to draw a comprehensive mechanism to explain the local lesions observed in this type of envenoming.

In the present study it is show $\mathrm{n}$ that oedema and haemorrhage induced by $B$. jararaca venom have distinct pharmacological mediation and our results suggest that haemorrhage is partially controlled by serotonin and neurogenic mediators.

\section{Methods}

\section{Venoms}

A pool of lyophilised venom obtained from adult specimens of B. jararaca snakes, supplied by the Laboratory of Herpetology, Instituto Butantan, was used throughout this investigation. The venom was kept at $-20^{\circ} \mathrm{C}$, and venom solutions were prepared $(\mathrm{w} / \mathrm{v})$ with sterile saline just before use. 


\section{Animals}

Male Wistar rats $(220-250 \mathrm{~g})$ or male Swiss mice $(18-22 \mathrm{~g})$ were used. The animals were maintained with water and food ad libitum in appropriate environment conditions and used under e thic al conditions, according to guidelines of the International Socie ty of Tox inology. ${ }^{30}$

\section{Morphology of venom-induced lesions}

Rats, maintained under ether anaesthesia, were injected into the subcutaneous tissue of the scrotal bag with $2.5 \mu \mathrm{g}$ of venom $(50 \mu \mathrm{l})$ in saline. Control rats received the same volume of saline. One minute after the injection, animals were killed and samples of tissue from injected areas were obtained. In order to evaluate the role played by blood circulation in the evolution of the venom-induced lesions, the same procedure as above was performed in rats whose heartbeats had just stopped due to prolonged ether anaesthesia. Tissue samples from the sites of venom injection were collected $1 \mathrm{~min}$ after the injection and fixed in $2.5 \%$ buffered glutaraldehyde. Routine double fixation, embedding in Araldite and staining with uranyl acetate and lead citrate were employed. The processed samples were analysed in a Phillips (EM201) electron microscope.

\section{Evaluation of haemorrhage and oedema}

Local haemorrhage and oedema were simultaneously evaluated using a modification of the methods described by Ow nby et al. ${ }^{31}$ and by Yamakaw a $e$ a $a . .^{32}$ Mice were injected s.c. in the right foot pad with $50 \mu \mathrm{l}$ of the venom solution. The contra-lateral foot pad received the same volume of sterile saline. Three hours later (time determined by a time-course experiment for haemorrhage and oedema), the animals were sacrificed in an ether chamber. The paws were removed at the level of the tibio-tarsic junction, weighted, fragmented and put in tubes containing $4 \mathrm{ml}$ of von Kampen-Zijlstra reagent modified by Matsubara et al. ${ }^{33}\left(200 \mathrm{mg} \mathrm{K}_{3}\left[\mathrm{Fe}(\mathrm{CN})_{6}\right], 50 \mathrm{mg} \mathrm{KCN}\right.$, $120 \mathrm{mg} \mathrm{KH}_{2} \mathrm{PO}_{4}, 50 \mathrm{mg} \mathrm{NaCl}$ and $1 \mathrm{ml}$ non-ionic detergent per litre). The tissue was homogenised and the tubes were centrifuged at $3000 \mathrm{~g}$ for $30 \mathrm{~min}$. The supernatant was filtered in Millipore membranes $(0.8 \mu$ pores $)$, and the absorbance at $540 \mathrm{~nm}$ was determined in a spectrophotometer (Micronal B382, Brazil).

The haemoglobin concentration was determined as follows:

$$
[\mathrm{Hb}]=\frac{\mathrm{A} 540 \mathrm{~nm} \times 64.458}{44 \times d \times 1000}
$$

where: $[\mathrm{Hb}]=$ haemoglobin concentration; $\mathrm{A} 540 \mathrm{~nm}=$ absorbance obtained; $64.458=$ molecular weight of haemoglobin; $44=44 \mathrm{mmol}^{-1} / \mathrm{cm}=$ molecular absorption of hae moglobin; $d=1=$ cuvette thickness; $1000=$ converting factor (litre to millilitre); $4=$ volume of von Kampen-Zijlstra reagent.

In order to eliminate the influence of oedema, the concentration of haemoglobin obtained in the paw injected with venom was divided by the weight of the paw injected with saline. The difference between haemoglobin content of the paw injected with venom and of that injected with saline was the estimated haemorrhage, expressed as $\mathrm{mg} \mathrm{Hb} / \mathrm{g}$ of tissue. The minimal haemorrhagic dose (MHD) was defined as the minimal concentration of venom able to induce an increase of three times the haemoglobin concentration in relation to that of a control tissue. Finally, oedema, expressed in $\mathrm{mg}$, was evaluated by the difference in weight between one paw injected with venom and the other injected with saline. ${ }^{32}$

\section{Treatment of animals}

Groups of 6 to 10 mice were injected s.c. into the foot pad with $5 \mathrm{MHD}$ of the venom $(5 \mu \mathrm{g}$ in $50 \mu \mathrm{l})$ after the following treatments: (1) dexamethasone (corticosteroid, phospholipase $\mathrm{A}_{2}$ inhibitor: Decadron ${ }^{\circledR}$, Promade, Brazil), 1 and $0.4 \mathrm{mg} / \mathrm{kg}$, i.p., 24 and $1 \mathrm{~h}$ before the venom; (2) indomethacin (inhibitor of the prostaglandin-forming cyclooxigenase: Sigma), $30 \mathrm{mg} / \mathrm{kg}$, s.c., $30 \mathrm{~min}$ before the venom; (3) methysergide (5HT receptor antagonist: Sigma), $0.8 \mathrm{mg} / \mathrm{kg}$, s.c., $30 \mathrm{~min}$ before the venom; (4) promethazine $\left(\mathrm{H}_{1}\right.$ receptor antagonist: Rhodia Pharma, Brazil), $10 \mathrm{mg} / \mathrm{kg}$, i.p., $30 \mathrm{~min}$ before the venom; (5) mepyramine $\left(\mathrm{H}_{1}\right.$ receptor antagonist: Sigma), $5 \mathrm{mg} /$ $\mathrm{kg}$, i.p., $30 \mathrm{~min}$ before the venom; (6) morphine (opioid: Merck), $30 \mathrm{mg} / \mathrm{kg}$, s.c., $30 \mathrm{~min}$ before the venom; (7) guane thidine (peripheral post-ganglionic adrenergic neurone inhibitor; sympathetic blockade: Ciba Geigy), three doses of $30 \mathrm{mg} / \mathrm{kg}$, s.c., with $24 \mathrm{~h}$ intervals, before the venom injection; (8) chronic denervation: mice were anaesthetised with a Ketalar ${ }^{\circledR}$ (Park-Davis) - Rumpum ${ }^{\circledR} \quad$ (Bayer) solution $(1: 2 \mathrm{v} / \mathrm{v}$, diluted $1: 4 \mathrm{v} / \mathrm{v}$ in saline $)$, i.p., $0.1 \mathrm{ml} / 10 \mathrm{~g}$ body weight, and the sciatic and saphenous nerves of the right leg were surgically sectioned and the venom injected into the right foot pad 7 days later; (9) capsaicin (substance P releaser from sensory afferent neurones: Merck), $50 \mathrm{mg} / \mathrm{kg}$, s.c., on the second day after birth (in neonate animals, capsaicin treatment causes degeneration of sensory afferent neurones) (animals were used when they achieved the appropriate weight); (10) respective control groups received saline by the same route. In the case of the chronic denervation, control animals were sham operated, and in the case of the capsaicin, control group received the capsaicin solvent. 

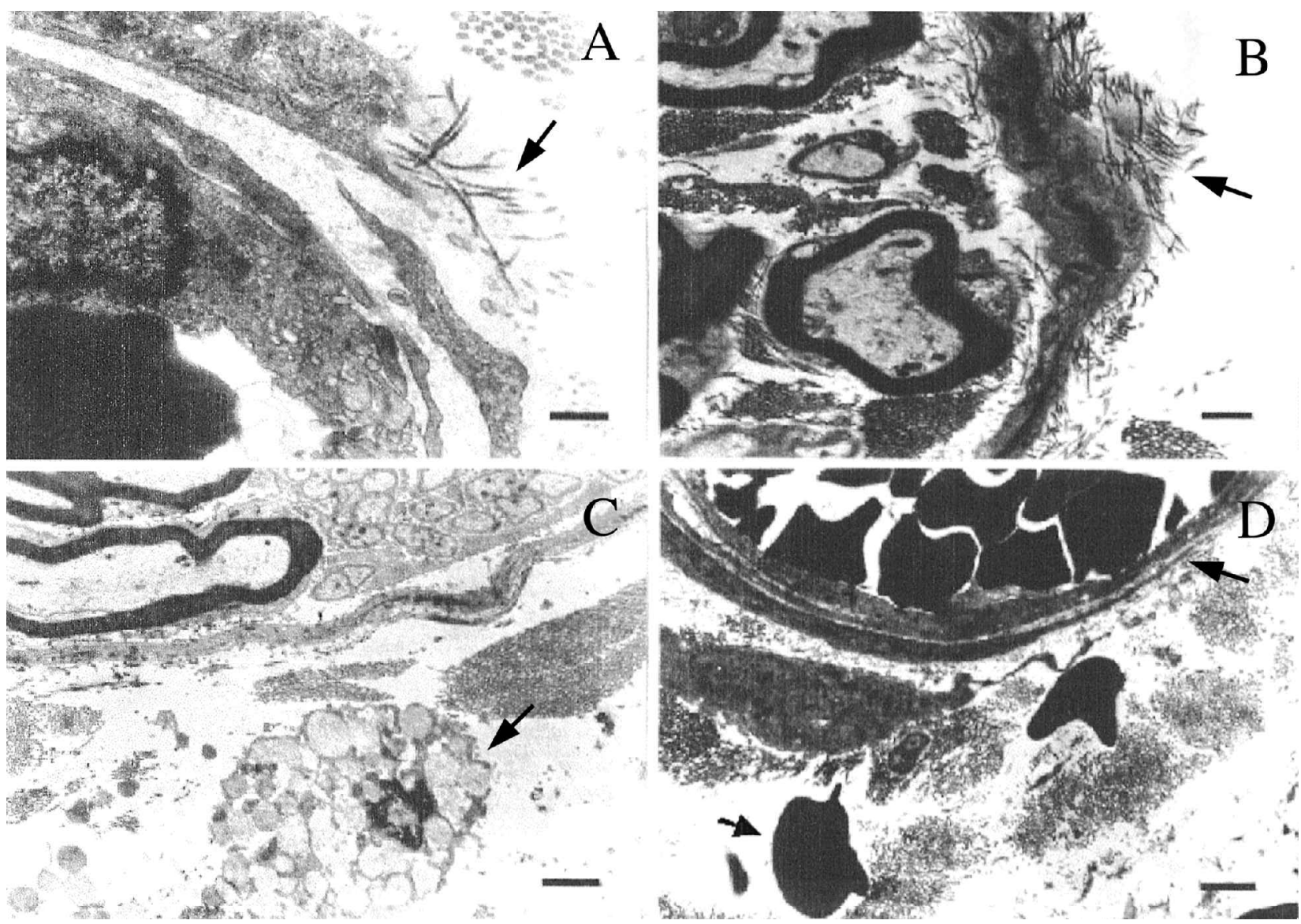

FIG. 1. Electron micrographs of the connective tissue of scrotal bag of a rat $1 \mathrm{~min}$ after injection of $2.5 \mu \mathrm{g}$ of $B$. jararaca venom. Arrows indicate: $(A)$ disorganisation of perivascular collagen fibres (bar $=0.25 \mu \mathrm{m}$ ); $(B)$ disorganisation of perineural collagen fibres (bar $=0.5 \mu \mathrm{m})$; (C) mast cell degranulation near a nerve bundle (bar $=1 \mu \mathrm{m})$; and (D) vascular congestion and haemorrhage $(\mathrm{bar}=1 \mu \mathrm{m})$.

\section{Statistics}

Results were analysed by Student's t-test and considered significantly different when $\mathrm{p}<0.05$.

\section{Results}

\section{Morphology of the envenomed connective tissue}

Disorganisation of collagen fibres, particularly near blood vessels and nerve bundles (Fig. 1A and 1B, respectively), mast cell degranulation (Fig. 1C) and intense vascular congestion (Fig. 1D) were observed $1 \mathrm{~min}$ after venom injection into the subcutaneous tissue of the scrotal bag of rats. Morphological alterations in venular endothelial cells were not clearly detected, although red blood cells were seeing squeezing out through open endothelial cell junctions, characterising a per diapedesis type of haemorrhage (Fig. 2). Alterations such as disorganisation of collagen fibres and mast cell degranulation were not observed when the venom was injected into the s.c. tissue of clinically dead animals.

\section{Time-course of haemorrhage and oedema} induced by the venom

Haemorrhage induced by $1.25 \mu \mathrm{g}$ of venom showed a peak at the 3rd hour after injection, persisting up to $6 \mathrm{~h}$. Oedema was maximal from $30 \mathrm{~min}$ up to $3 \mathrm{~h}$, decreasing after $6 \mathrm{~h}$ of venom injection. As both haemorrhage and oedema were maximal $3 \mathrm{~h}$ after venom injection, this time was selected to evaluate some parameters of the pharmacological mediation of these processes.

The haemorrhagic activity was dose-dependent, and the MHD obtained was $0.95 \mu \mathrm{g}$. A dose of $5 \mu \mathrm{g}$ of venom was used for the study of the pharmacological mediation of the lesions.

\section{Mediation of venom-induced haemorrhage and oedema}

With the dose of venom used, only local events were evaluated, as it was considered that envenomed mice do not present such systemic effects as blood incoagulability or thrombocytopenia (data not shown). Dexamethasone and indomethacin treat- 


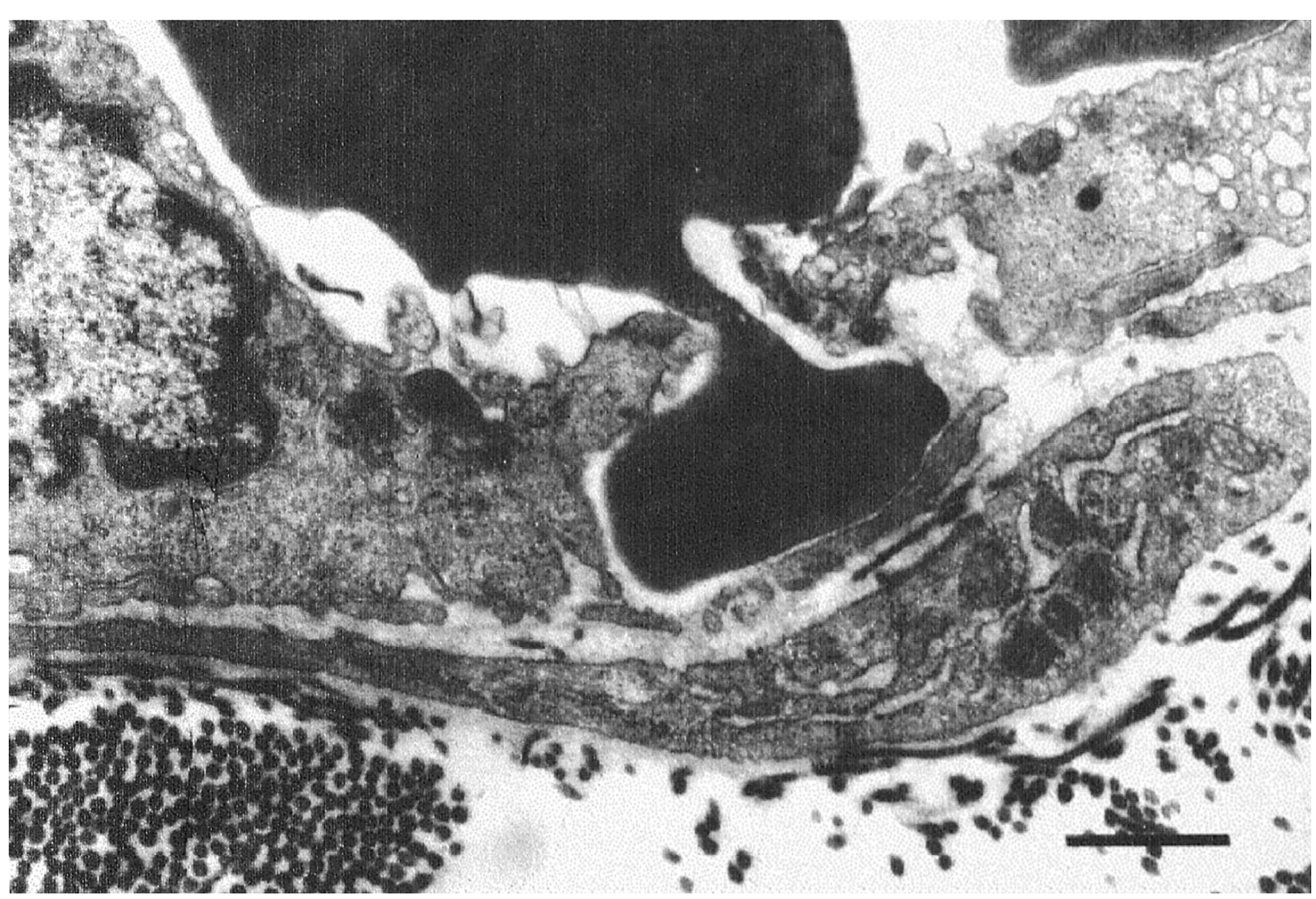

FIG. 2. Electron micrograph of a venule $1 \mathrm{~min}$ after injection of $2.5 \mu \mathrm{g}$ of $B$. jararaca venom showing an erythrocyte escaping through an endothelial junction (bar $=0.5 \mu \mathrm{m}$ ).

ments did not alter the haemorrhagic pattern induced by the venom, but significantly inhibited oedema (Fig. $3)$. Pre-treatment with morphine or methysergide inhibited both haemorrhage and oedema (Fig. 4), and guanethidine, surgical denervation and capsaicin treatments significantly inhibited haemorrhage, but not oedema induced by the venom (Fig. 5). In promethazine or mepyramine treated animals, oedema and haemorrhage were not affected.

\section{Discussion}

Local haemorrhage induced by snake venoms is credited to metalloproteinases present in these venoms. ${ }^{6}$ This effect has been associated with the activity of these toxins on proteins of the extracellular matrix..$^{6,12}$

In the present study, the injection of a low dose of $B$. jararaca venom into the connective tissue of the scrotal bag of rats induced prompt and significant alterations to the morphology of this tissue. The premature manifestation of these alterations contrast with the long time (hours) needed for the in vitro degradation of proteins of extracellular matrix by haemorrhagic factors isolated from viperid ven-
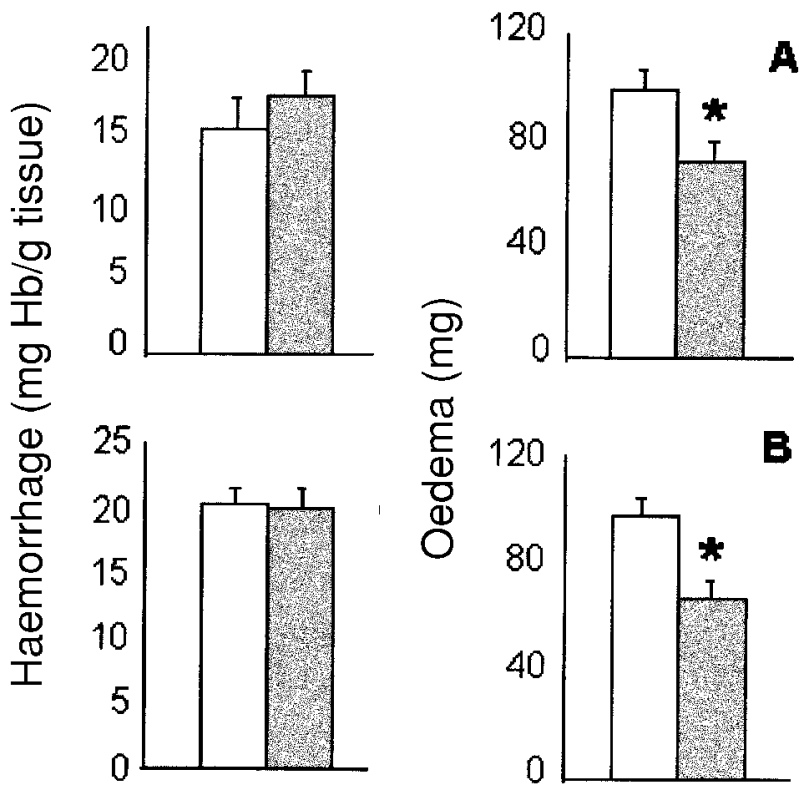

FIG. 3. Effect of treatments with (A) dexamethasone and (B) indomethacin on $B$. jararaca-induced haemorrhage and oedema. Mice treated with (A) dexamethasone (1 and $0.4 \mathrm{mg} / \mathrm{kg}$, i.p., 24 and $1 \mathrm{~h}$ before the venom) or (B) indomethacin $(30 \mathrm{mg} / \mathrm{kg}$, s.c., $30 \mathrm{~min}$ before the venom) received $5 \mu \mathrm{g}$ of $B$. jararaca venom into the foot pad. Haemorrhage and oedema in treated animals (dark bars) were compared with results obtained in saline treated control groups (white bars). Mean \pm SE. ${ }^{*} p<0.05$. 

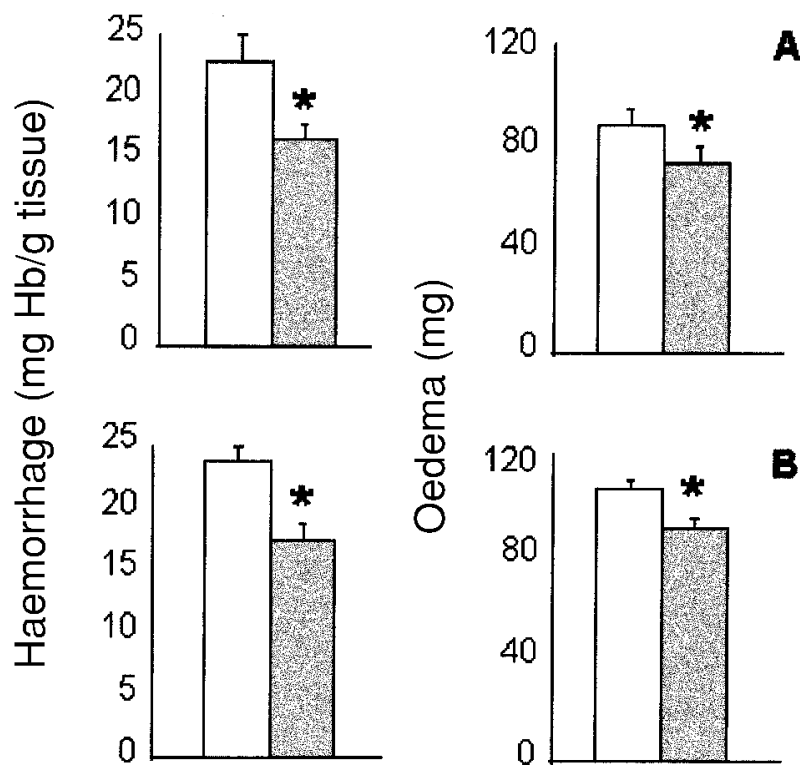

FIG. 4. Effect of treatments with (A) methysergide and (B) morphine on $B$. jararaca-induced haemorrhage and oedema. Mice were treated with $(A)$ methysergide $(0.8 \mathrm{mg} / \mathrm{kg}$, s.c.) or (B) morphine $(30 \mathrm{mg} / \mathrm{kg}$, s.c. $), 30 \mathrm{~min}$ before $B$. jararaca venom injection $(5 \mu \mathrm{g})$ into the foot pad. Haemorrhage and oedema in treated animals (dark bars) were compared with results obtained in saline treated control groups (white bars). Mean \pm SE. ${ }^{*} p<0.05$.

oms. ${ }^{13-17}$ Moreover, the absence of alterations such as disorganisation of collagen fibres and degranulation of mast cells, when the venom was injected into the connective tissue of rats immediately after ceasing heartbeat, suggest that such an effect depends on the mediation of some factor(s) liberated from injected tissue, and possibly from the active blood circulation.

The possible participation of mediators from the damaged tissue in the pathogenesis of local haemorrhage induced by the venom was tested in paw of mice submitted to pharmacological or surgical treatments and compared with the mediation of the oedema induced by the venom in the same paw. As show $\mathrm{n}$ in the Results section, the major mediators of oedema induced by this venom were derivatives of arachidonic acid, since treatments with dexamethasone (phospholipase $\mathrm{A}_{2}$ inhibitor) or indomethacin (cyclooxigenase inhibitor) were effective in inhibiting this effect. These results are in agreement with data from Trebien and Calix to ${ }^{19}$ and Perales et al. ${ }^{21}$ The participation of these mediators in the process was also demonstrated for other viperid venom-induced oedema. ${ }^{18,23}$ While histamine seems to play a minor role in oedema induced by $B$. jararaca venom in rats, ${ }^{19}$ in mice this vasoactive amine does not participate at all in the process, confirming previous observations made by Perales et al. ${ }^{21}$ By contrast to the observations of these authors, we found that serotonin partially mediates venom-induced oedema,

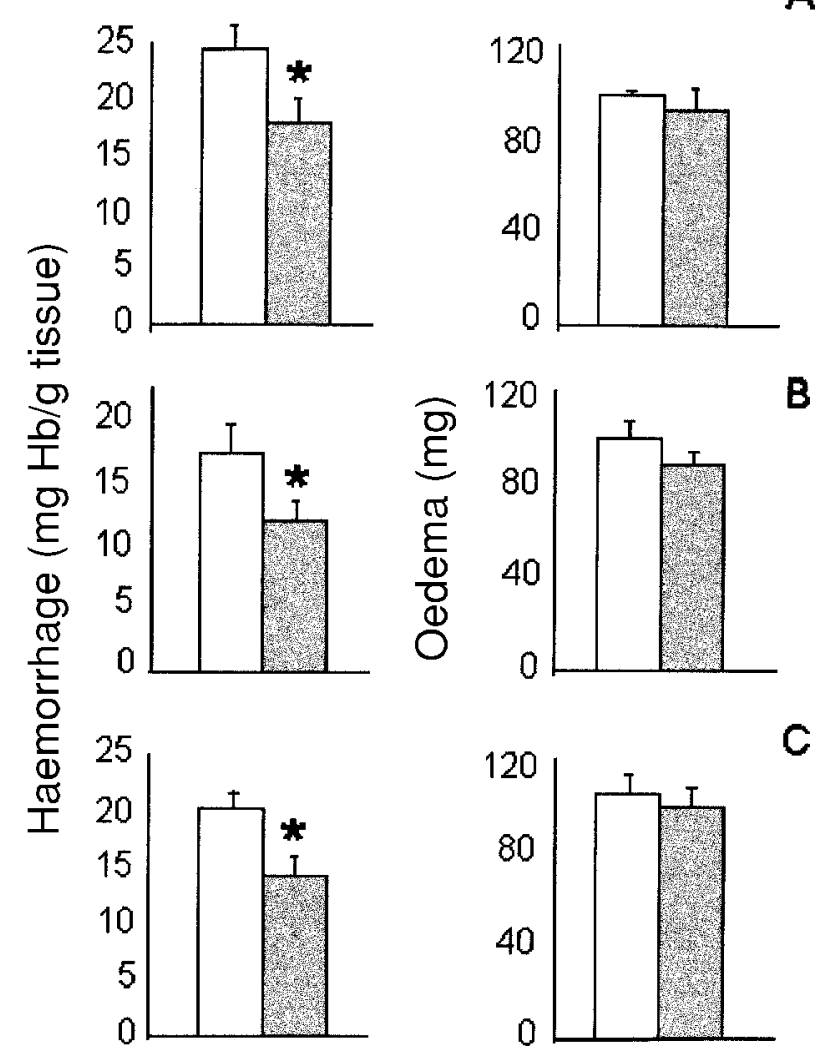

FIG. 5. Effect of treatments with (A) capsaicin, (B) guanethidine and (C) surgical denervation on $B$. jararaca-induced haemorrhage and oedema. Mice were treated with (A) capsaicin ( $50 \mathrm{mg} / \mathrm{kg}$, s.c., on the $2 \mathrm{nd}$ day after the birth), (B) guanethidine ( 3 doses of $30 \mathrm{mg} / \mathrm{kg}$, with $24 \mathrm{~h}$ intervals, lasting $24 \mathrm{~h}$ before the venom) or (C) surgical denervation by sciatic and saphenous nerve section, 7 days before the venom injection. Animals received $5 \mu \mathrm{g}$ of $B$. jararaca venom into the foot pad. Haemorrhage and oedema in treated animals (dark bars) were compared with results obtained in saline treated control groups (white bars). Mean \pm SE. ${ }^{*} p<0.05$.

considering that pre-treatment of the animals with methysergide decreased the intensity of the process.

The oedema induced by $B$. jararaca venom seems to be also mediated by opioid receptors, considering that treatment of the animals with morphine inhibits the process. This inhibitory effect of morphine was also demonstrated for oedema caused by other viperid venom (Trimeresurus flavoviridis) ${ }^{20}$, as well as that caused by other flogistic agents such as carrageenan. ${ }^{34}$ Nevertheless, the mechanisms which underlie the anti-oedematogenic effect of morphine are not yet understood.

Our results indicate that the mediation of oedema formation differs from that involved in the induction of haemorrhage. Based on results obtained in mice pre-treated with dexamethasone or indomethacin, arachidonic acid derivatives seems not to participate in the local haemorrhage induced by $B$. jararaca venom, confirming previous observations by Perales et al. ${ }^{21}$ Conversely, in mice pre-treated with guanethi- 
dine, capsaicin or surgical denervation, local haemorrhage but not oedema was attenuated. On the other hand, methysergide or morphine significantly diminished both oedema and haemorrhage, indicating that, at least in mice, serotonin and opioid receptors are partially implicated in both effects. The fact that partial inhibition was obtained with these treatments suggests that haemorrhage and oedema are indeed multimediated phenomena.

The participation of opioid receptors in inflammatory events, as well as the relationship between antidromic stimulation of sensitive nerve fibres and vascular permeability disturbance, have been demonstrate d. ${ }^{20,34-43}$ It is know $n$ that neuropeptides, particularly substance $\mathrm{P}$, can induce a direct vascular disturbance or may act indirectly by inducing liberation of histamine from mast cells. ${ }^{39}$ Added to this hypothesis is the fact that the blockade of opioid receptors (e.g. treatment with morphine) can prevent the liberation of substance P. ${ }^{44,45}$ These results, and the inhibition of haemorrhage observed in animals treated with capsaicin or which are chronically denervated, strongly indicate that haemorrhage induced by the venom could be classified as a neurogenic type of haemorrhagic inflammatory response. Reinforcing this interpretation is the fact that neurogenic vascular disturbances can be inhibited by sectioning nerve routes or by chemical depletion of neuropeptides after capsaicin tre atment. ${ }^{36}$

Taken together, these data might explain the explosive alterations in the connective tissue of rats $1 \mathrm{~min}$ after venom injection. Malucelli and Mariano ${ }^{40}$ also observed a similar phenomenon of instantaneous haemorrhagic response on the diaphragm of guinea pigs after electric or chemical stimulation of the phrenic nerve. These authors described a per diapedesis haemorrhage in diaphragmatic vessels. Furthermore, this type of haemorrhage was also observed after T. flavoviridis venom injection. ${ }^{46}$ Conversely, after intramuscular injection of various viperid crude venoms or isolated haemorrhagic factors, the usual feature is a per rhexis haemorrhage observed in capillaries. ${ }^{47-49}$ Whether these differences are due to the dose of venom injected, the route of injection or other peculiar characteristics of the microvasculature in these tissues remains to be investigated. It must be considered that per diapedesis haemorrhage is mainly observed in venules while per rhexis hae morrhage is reported to occur mainly in capillaries. Nevertheless, only vessels greater than $20 \mu \mathrm{m}$ in diameter, like venules, are innervated. ${ }^{50}$ This fact and results here described indicate that per diapedesis haemorrhage induced by $B$. jararaca venom can be controlled by neurogenic factors. Further studies should be made in order to identify the specific neurogenic factor(s) involved in this process.
In conclusion, our results suggest that local haemorrhage induced by $B$. jararaca venom is partially mediated by serotonin and by neurogenic factors. Furthermore, they show that oedema and local haemorrhage induced by this venom have distinct chemical mediation.

ACKNOWLEDGEMENTS. The authors thank Mrs Maria Christina Gaviolli for the electron microscopy preparations. This work was a partial requirement for obtaining MSc degree by LRCG, at the Department of Pathology, School of Veterinary Medicine, Unive rsity of São Paulo, Brazil.

\section{References}

1. Rosenfeld G. Symptomatology, pathology, and treatment of snake bites in South America. In: Bücherl W, Buckley E, eds Venomous Animals and Their Venoms. New York: Academic Press, 1971: 345-84

2. Cardoso JLC, Fan HW, França FOS. Randomized comparative trial of three antivenoms in the treatment of envenomation by lance-headed viper (Bothrops jararaca) in São Paulo, Brazil. Quart J Med 1993: 86:315-25

3. Gutiérrez JM, Chaves F, Bolaños R, Cerdas L, Rojas E, Arroyo O, Portilla E. Neutralización de los efectos locales del veneno de Bothrops asper por un antiveneno polivalente. Toxicon 1981: 19:493-500

4. Gutiérrez JM, Rojas G, Lomonte B, Gené JA, Cerdas L. Comparative study of the oedema-forming activity of Costa Rican snake venoms and its neutralization by a polyvalent antivenom. Comp Biochem Physiol 1986: 85C: $175-80$

5. Gutiérrez JM, León G, Rojas G, Lomonte B, Rucavado A, Chaves F. Neutralization of local tissue damage induced by Bothrops asper (terciopelo) snake venom. Toxicon 1998: 36:1529-38

6. Bjarnason JB, Fox JW. Haemorrhagic metalloproteinases from snake venoms. Pharmac Ther 1994: 62:325-72

7. Ohsaka A. Proteolytic activity of Habu snake venom and their separation from le thal toxicity. Japan J Med Sci Biol 1960: 13:33-41

8. Ohsaka A, Ikezawa H, Kondo H, Kondo S, Ushida N. Haemorrhagic activity of Habu snake venom, and their lethal toxicity, proteolytic and other pathological activities. Br J Exp Pathol 1960: 41:478-86

9. Maeno H. Biochemical analysis of pathological lesions caused by Habu snake venom with special reference to haemorrhage. J Biochem 1962: 52:343-50

10. Omori T, Iwanaga $S$, Suzuki T. The relationship between the haemorrhagic and lethal activities of Japanese Mamushi (Agkistrodon halys blom hoffii) venom. Toxicon 1964: 2:1-4

11. Toom PM, Squire PG, Tu AT. Characterization of the enzymatic and biological activities of snake venoms by isoeletric focusing. Biochim Biophys Acta 1969: 181:339-41

12. Ohsaka A, Just M, Habermann E. Action of snake venom haemorrhagic principle on isolated glomerular basement me mbrane. Biochem Biophys Acta 1973: 323:415-28

13. Bjarnason JB, Hamilton D, Fox JW. Studies on the mechanism of haemorrhage production by free proteolytic haemorrhagic toxin from Crotalus atrox venom. Biol Chem Hoppe-Seyler 1988: 369(Supp1.):121-9

14. Baramova EN, Shannon JD, Bjarnason JB, Fox JW. Degradation of extracellular matrix proteins by metalloproteinases. Arch Biochem Biophys 1989: 275:63-71

15. Shannon JD, Baramova EN, Bjarnason JB, Fox JW. Amino acid sequence of Crotalus atrox venom metallop roteinase which cleaves Type IV collagen and gelatin. J Biol Chem 1989: 264:11575-83

16. Baramova EN, Shannon JD, Bjarnason JB, Fox JW. Identification of the cleavage sites by a metalloproteinase in Type IV collagen. Matrix 1990: 10:91-7

17. Maruyama M, Tanigaw a M, Sugiki M, Yoshida E, Mihara H. Purification and characterization of low molecular weight fibrinolytic/haemorrhagic enzymes from snake (Bothrops jararaca) venom. Enzyme Protein 1993 47:124-35

18. Detrait J, Jacob J. Antagonism of mouse paw oedema induced by Habu snake (Trimeresurus flavoviridis) venom. Inhibition by various antagonists administered alone or in combinations. Japan J Exp Med 1988: 58:249-59

19. Trebien HA, Calix to JB. Pharmacological evaluation of rat paw oedema induced by Bothrops jararaca venom. Agents and Actions 1989: 26:292-300

20. Detrait J, Jacob J. Mouse paw oedema induced by Habu snake (Trimeresurus flavoviridis) venom. Inhibition by morphine, naloxone and methilnaloxone alone or in combinations. Japan J Exp Med 1990: 60: $187-96$

21. Perales J, Amorim CZ, Rocha SLG, Domont G, Moussatché H. Neutralization of the oedematogenic activity of Bothrops jararaca venom on the mouse paw by an antibothropic fraction isolated from opossum (Didelphis marsupialis) serum. Agents and Actions 1992: 37:250-9 
22. Cury Y, Teixeira CFP, Sudo L Edematogenic responses induced by Bothrops jararaca venom in rats: role of lymphocytes. Toxicon 1994: 32:1425-31

23. Chaves F, Barboza M, Gutiérrez JM. Pharmacological study of oedema induced by venom of the snake Bothrops asper (terciopelo) in mice. Toxicon 1995: 33:31-9

24. Teixeira CFP, Cury Y, Oga S, Jancar S. Hyperalgesia induced by Bothrops ja ra raca venom in rats: role of eicosanoids and platelet activating factor (PAF). Toxicon 1994: 32:419-26

25. Flores CA, Zappellini A, Prado-Franceschi J. Lipoxygenase-derived mediators may be involved in in vivo neutrophil migration induced by Bothrops erythromelas and Bothrops alternatus venoms. Toxicon 1993: 31:1551-9

26. Lomonte B, Tarkowski A, Hanson LA. Host response to Bothrops asper snake venom. Analysis of oedema formation, inflammatory cells, and cytokine release in a mouse model. Inflam mation 1993: 17:93-105

27. Búrigo AC, Calix to JB, Medeiros YS. Pharmacological profile of rat pleurisy induced by Bothrops jararaca venom. J Pharm Pharmacol 1996: 48:106-11

28. Farsky SHP, Costa-Cruz JWM, Cury Y, Teixeira CFP. Leukocyte response induced by Bothrops jararaca crude venom: in vivo and in vitro studies. Toxicon 1997: 35:185-93

29. Barros SF, Friedlanskaia I, Petricevich VL, Kipnins TL. Local inflammation and cytokine release in mice injected with Bothrops atrox venom. Mediators of Inflam mation 1998: 7:339-46

30. Meier J, Banks B, Creppy EE, Habermehl G, Kornalik F, Lee CY, Mebs D, Rosenberg P, Theakston RDG. Ethical standards for animal experiments in tox inological research. Toxicon 1993: 31:9-12

31. Ownby CL, Colberg TR, Odell GV. A new method for quantitating haemorrhage induced by rattlesnake venoms. Ability of polyvalent antivenom to neutralize haemorrhagic activity. Toxicon 1984: 22:227-33

32. Yamakawa M, NozakiM, Hokama Z. Fractionation of sakishima habu (Trimeresurus elegans) venom and lethal, haemorrhagic, and oedema forming activities of the fractions. In: Ohsaka A, Hayashi K, Saway Y, eds Animal, Plant, and Microbial Toxins. New York: Plenum Press, 1976 97-109

33. Matsubara T, Okuzono H, Tamagaw a S. Proposal for an improved reagent in haemoglobin cyanid method. In: International Congress of Hematology The Open Section of Expert Panel on Hemoglobinometry of the International Commitee for Standardization in Hematology. Munich 1970.

34. Joris J, Costello A, Dubner R, Hargreaves KM. Opiates suppress carragenan-induced oedema and hyperthermia at doses that inhibit hyperalgesia. Pain 1990: 43:95-103
35. Chapman LF, Goodell H. The participation of the nervous system in the inflammatory reaction. Ann N Y Acad Sci 1964: 116:990-1017

36. Jancsó N, Jancsó-Gabor A, Szolcsanyi, J. Direct evidence for neurogenic inflammation and its prevention by denervation and by pretreatment with capsaicin. Br J Pharmac Chemother 1967: 31:138-51

37. Brown J, Rissel J, Lish P. Studies on the acute inflammatory response. I. Involvement of the central nervous system in certain models of inflammation. J Pharmacol Exp Ther 1968: 160:231-42

38. Garcia Leme J, Hamamura L Formation of a factor increasing vascular permeability during electrical stimulation of the saphenous nerve in rats. Br J Pharmac 1974: 51:383-9

39. Lembeck F, Holzer P. Substance $P$ as neurogenic mediator of antidromic vasodilatation and neurogenic plasma ex travasation. Naunyn-Schmiedeberg's Arch Pharmacol 1979: 310:175-83

40. Malucelli BE, Mariano M. The haemorrhagic exudate and its possible relationship to neurogenic inflammation. J Pathol 1980: 130:193-200

41. Bartho Lo Szolcsanyi J. Opiate agonists inhibit neurogenic plasma extravasion in rat. Eur J Pharmacol 1981: 73:101-4

42. Gyiers K, Budavari I, Fürst S, Molòr I. Morphine inhibits the carragenan induced oedema and chemiluminescence of leukocytes stimulated by zymosan. J Pharmac Pharmacol 1985: 37:100-4

43. Casellas AM, Guardiola H, Renaud FL. Inhibition by opioids of phagocytosis in peritoneal macrophages. Neuropeptides 1991: 18:35-40

44. Jessel TM, Iversen LL. Opiate analgesic inhibits substance P release from rat trige minal nucleus. Nature 1977: 152:183-8

45. Vacca LL, Abrahams SJ, Naftchi NE. Effect of morphine on Substance P neurons in rat spinal cord: a preliminary study. Brain Res 1980: 48:397-400

46. Ohsaka A, Suzuki K, Ohashi M. The spurting of erythrocytes through junctions of the vascular endothelium treated with snake venom. Microvasc Res 1975: 10:208-13

47. Moreira L, Gutiérrez JM, Borkow G, Ovadia M. Ultrastructural alterations in mouse capillary blood vessels after experimental injection of ve nom from the snake Bothrops asper (terciopelo). Exp Mol Pathol 1992: 57:124-33

48. Ownby CL, Bjarnason JB, Tu AT. Haemorrhagic toxins from rattlesnake (Crotalus atrox) venom. Pathogenesis of haemorrhage induced by three purified toxins. Am J Pathol 1978: 93:201-18

49. Kamiguti AS, Theakston RDG, Desmond H, Hutton RA. Systemic haemorrhage in rats induced by a haemorrhagic fraction from Bothrops jararaca venom. Toxicon 1991: 29:1097-106

50. Böhm GM. Vascular events in inflammation. Agents and Actions 1977: 7(Sup p1.):31-50

\section{Accepted 1 May 2000}




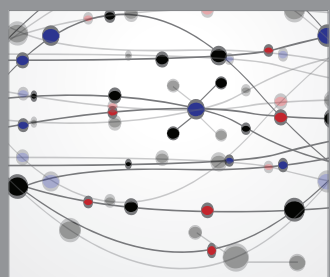

The Scientific World Journal
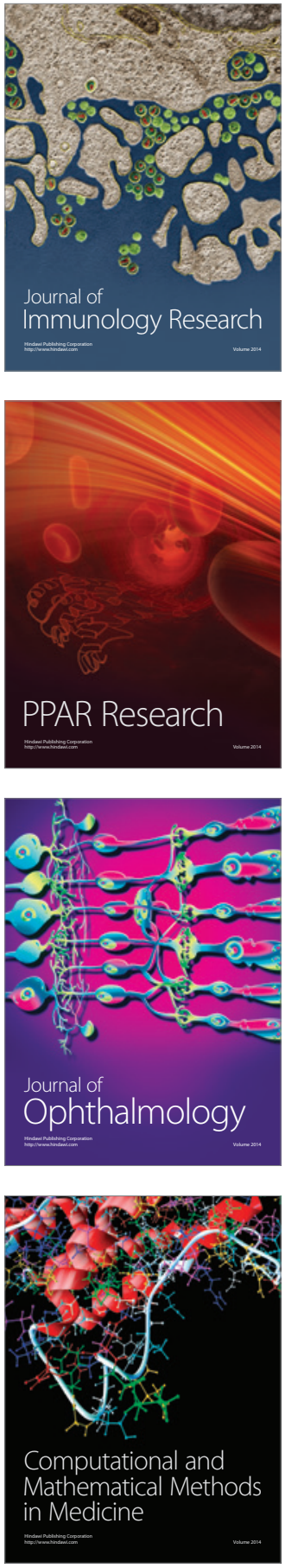

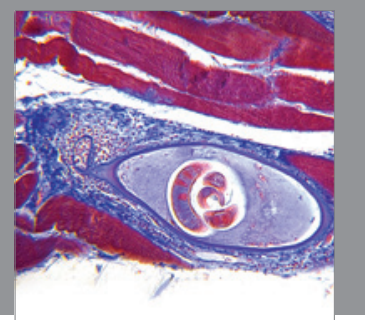

Gastroenterology

Research and Practice
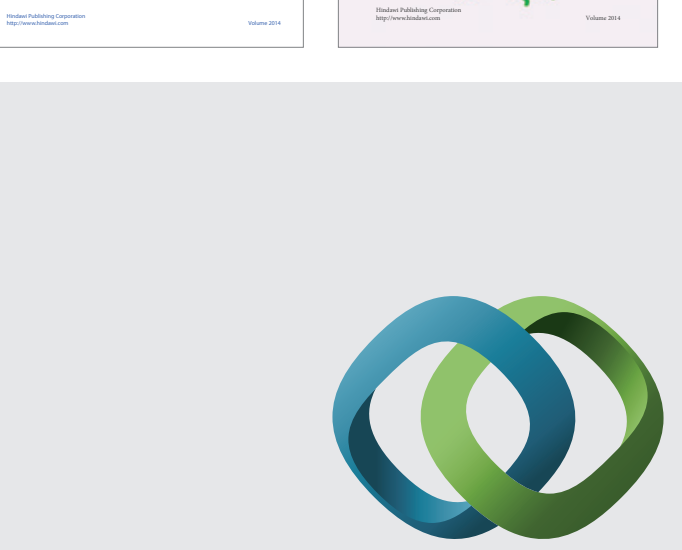

\section{Hindawi}

Submit your manuscripts at

http://www.hindawi.com
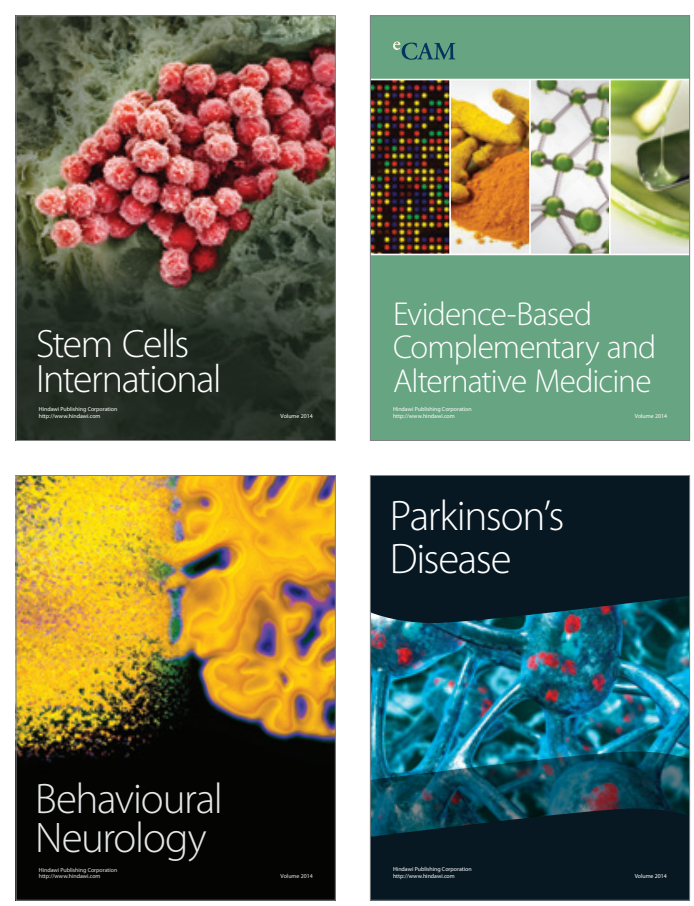

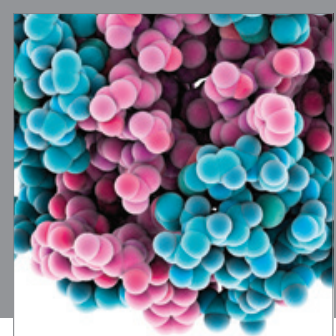

Journal of
Diabetes Research

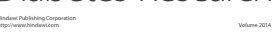

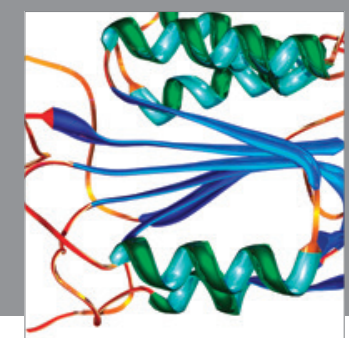

Disease Markers
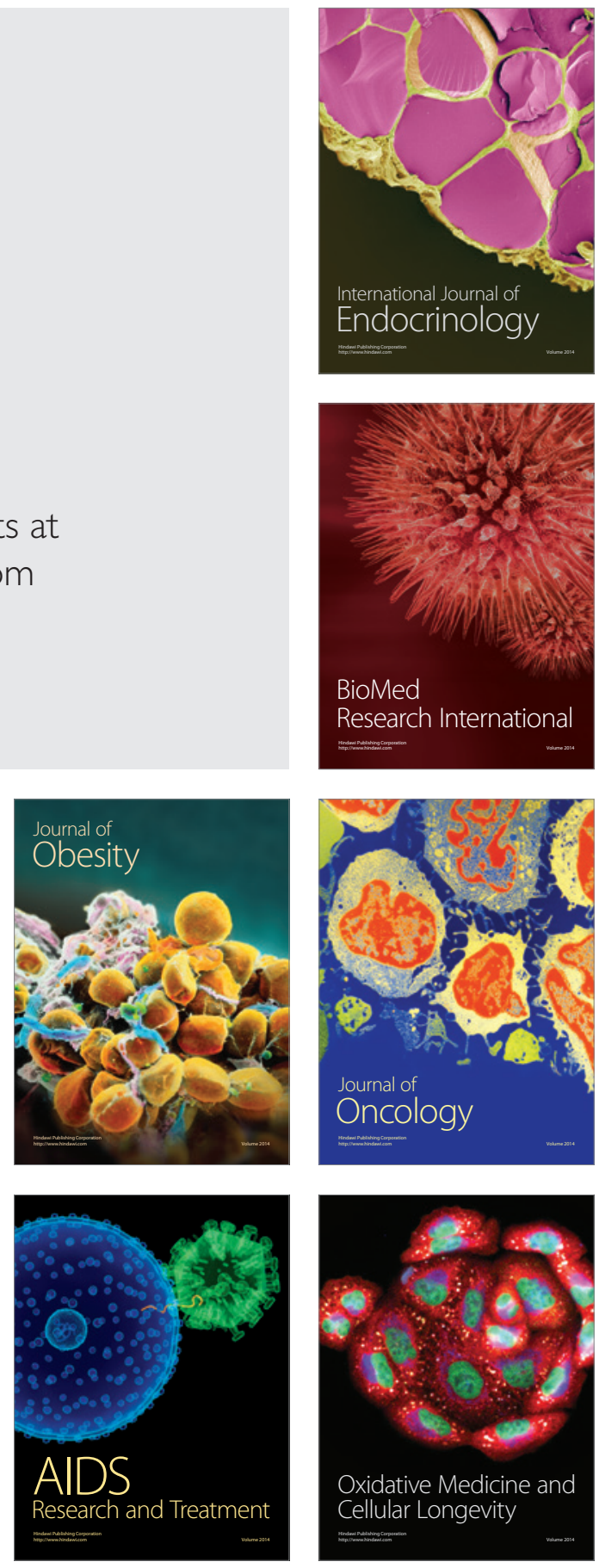